\title{
Un triángulo de paradojas. Gaceta Médica de México se publicará solo en forma electrónica
}

\author{
Alejandro Treviño-Becerra \\ Academia Nacional de Medicina de México, Gaceta Médica de México, Ciudad de México, México
}

Para tratar de encontrar una explicación satisfactoria considero que acontecen tres sucesos que convergen a manera de un triángulo escaleno, de lados desiguales, en cuyo centro se encuentra el cuerpo editorial de Gaceta Médica de México:

1. En un lado, la situación actual del país, con las políticas de reducción de gastos emprendidas desde la presidencia de la República.

2. En otro, el trabajo aislado que en ocasiones realizan las directivas y los editores de la revista.

3. En un tercer lado, el paradigma de la modernidad, que día con día nos lleva a territorios ambivalentes y que no tienen fin. Probablemente en poco tiempo aparecerá otro medio de comunicación que convierta en obsoleto al internet, como este lo está haciendo con la imprenta.

Ante el primero, la Academia Nacional de Medicina de México tiene voz en el Consejo de Salubridad General.

Respecto al segundo, los cuerpos editoriales de Gaceta han tenido autonomía para desarrollar su actividad editorial, pero dependen económicamente de la Academia Nacional de Medicina de México y la revista representa un lugar muy importante en los egresos de la Academia por gastos de publicación, traducción y distribución, aunado a que no está precisado si la anualidad que pagan los académicos de nuevo ingreso y numerarios cubre los ejemplares de Gaceta.

El tercero se refiere a la modernización de Gaceta y su inclusión en los ambientes electrónicos, que inició en 2008 con la edición simultánea en línea y continuó con la edición electrónica en inglés a partir de 2014, a lo que se sumó la profesionalización editorial con la compañía Permanyer. Todo ello ha implicado la elevación progresiva de los costos. Por otro lado, la revista aumentó el número de páginas a 144 y el tiraje a 2000 ejemplares y en los tres últimos años ha mejorado el diseño de la portada, algunas imágenes se imprimen a color y el cuidado de la edición se ha profesionalizado, lo que ha llevado a que un mayor número de colegas aspiren a publicar en esta revista (en el primer trimestre de 2019 se recibieron 147 manuscritos).

La paradoja es que ahora que la Gaceta ha mejorado su versión impresa, mantenida a lo largo de 154 años de existencia, por condiciones económicas y de modernidad tecnológica se acerca a su fin.

Recordaré que en la encuesta de 2017, respondida por 235 académicos, $86 \%$ de ellos señaló que deseaba seguir recibiendo la revista impresa y mantener la edición en línea. En el simposio sobre Revistas Médicas Nacionales, en el Congreso de la Academia en Monterrey, se vio claramente la tendencia de otras connotadas publicaciones médicas al formato electrónico. A principios de marzo de este año, por indicación de la directiva, envié por vía electrónica un cuestionario de una sola pregunta, que respondieron 148 académicos (los que dominan el internet): $25 \%$ mencionó que deseaba recibir Gaceta Médica de México de forma impresa. Por su parte, la directiva de la Academia envío a su vez un cuestionario de tres preguntas: de 70 encuestados, $25 \%$ manifestó el deseo de que se continúe con la edición impresa de Gaceta Médica de México. Aparentemente es mayor el número de los académicos que no desea recibir la Gaceta impresa, lo cual parece contradictorio al espíritu humanista de los académicos.

Probablemente los expertos señalen que las tres encuestas son metodológicamente deficientes y las preguntas sencillas y directas; algunos académicos
Fecha de recepción: 15-05-2019

Fecha de aceptación: 16-05-2019 DOI: 10.24875/GMM.19005276
Gac Med Mex. 2019:155:219-220

Disponible en PubMed www.gacetamedicademexico.com 
preguntarán si el muestreo fue aleatorio, si se mantuvo la tendencia y si con $10 \%$ de respuestas se puede tomar una decisión tan importante.

En la búsqueda de opiniones sobre la disminución del tiraje o la desaparición de la forma impresa de nuestra revista, comenté con anteriores editores de la revista: el doctor Francisco Olvera Esnaurrizar, quien fuera editor asociado en los años 1960 y 1961, comentó que no podía desaparecer la revista y que bien podría pedírsele a cada académico cinco pesos a la semana o encontrar un mecenas para mantenerla. Por su parte, el doctor Silvestre Frenk (editor por 25 años) envió un correo electrónico en el que expresaba su sentir: "Me parece que incorporarse a la era digital es una consecuencia inevitable de los tiempos actuales, incluida la Gaceta Médica de México. De modo que no me queda más que decir precisamente eso: ni modo".

Algunas sugerencias recibidas han sido reducir el tiraje, el número de páginas, la calidad del papel, cobrar el envío, insertar anuncios comerciales, cobrar más por los suplementos, reducir los gastos; sin embargo, ninguna de estas medidas llegaba a ajustar el monto que se requiere para imprimir al menos 100 ejemplares bimestralmente, aunado a otras situaciones ambientales y logísticas.

Considero que el asunto merecería más participación de los propios académicos, tanto jóvenes como veteranos, modernistas o conservadores. Personalmente estoy a favor de bajar los costos de producción y mantener una edición en papel reducida de Gaceta Médica de México y no quisiera que posteriormente aparezcan voces inconformes censurando la desaparición del impreso.

Los resultados de esta decisión se verán con el paso de los años. La presidente de la Academia Nacional de Medicina de México y el editor podrán ser recordados como los que cancelaron la forma impresa de Gaceta Médica de México o como los que decidieron, movidos por las circunstancias que mencioné sobre el triángulo escaleno, que en el futuro solo exista la revista virtual en español e inglés. El transcurso de los años mostrará si habrá reducción o aumento de trabajos para publicación y de lectores, así como las repercusiones sobre el factor de impacto y otros índices bibliométricos. Debemos cuidar que nuestra revista electrónica no vaya a confundirse con los cientos de publicaciones médicas on line que proliferan día a día e, incluso, se incrementan de manera progresiva sin fundamento científico ni calidad editorial.

Los editores en funciones -editor jefe, editor ejecutivo, editores asociados- continuamos trabajando con entusiasmo y dedicación en este periodo de transición para preservar la misión humanística de Gaceta Médica de México. 